\title{
IDENTIFIKASI BAKTERI Salmonella sp. PADA PENDERITA DEMAM TIFOID ANAK USIA 5-14 TAHUN DENGAN METODE WIDAL TEST DI RUMAH SAKIT ADVENT MEDAN TAHUN 2018
}

\author{
Mulya Sundari ${ }^{1}$, Debie Rizqoh ${ }^{2 *}$, Grace Junita Bate'e ${ }^{3}$ \\ ${ }^{1}$ Program Studi Profesi Kedokteran, Fakultas Kedokteran dan Ilmu Kesehatan, Universitas \\ Bengkulu \\ Email: mulyasundari@gmail.com \\ ${ }^{2}$ Departemen Mikrobiologi dan Imunologi, Fakultas Kedokteran dan Ilmu Kesehatan, \\ Universitas Bengkulu \\ *Email:debierizqoh@unib.ac.id \\ ${ }^{3}$ Program Studi Analis Kesehatan, Fakultas Farmasi dan Ilmu Kesehatan, Universitas Sari \\ Mutiara Indonesia \\ Email: gracejunita96@yahoo.com
}

Received: Januari 2021; Accepted: April 2021; Published: Juni 2021

\begin{abstract}
ABSTRAK
Demam tifoid merupakan suatu penyakit sistemik akut yang disebabkan oleh Salmonella typhi, Salmonella paratyphi A, Salmonella paratyphi B dan Salmonella paratyphi C. Penularan demam tifoid terjadi secara fekal-oral melalui makanan dan minuman yang terkontaminasi yang masuk kedalam tubuh.Pada anak-anak demam tifoid dapat terjadi akibat kurang memperhatikan kebersihan diri dan kebiasaan jajan yang sembarangan sehingga dapat menyebabkan tertular penyakit demam tifoid.Telah dilakukan penelitian terhadap 10 serum penderita demam tifoid anak usia 5-14 tahun di Rumah Sakit Advent Medan, dengan identifikasi bakteri Salmonellamelalui Uji Widal.Hasil yang telah di peroleh yaitu 1 orang pasien positif terhadap Salmonella typhii;1 orang pasien positif terhadap Salmonella typhii dan Salmonella paratyphii B; 3 orang pasien positif terhadap Salmonella typhii, Salmonella paratyphii $B$ dan Salmonella paratyphii $C ; 2$ orang pasien positif terhadap Salmonella typhii, Salmonella paratyphii A dan Salmonella paratyphii C; 1 orang pasien positif terhadap Salmonella paratyphii A, Salmonella paratyphii B dan Salmonella paratyphii $C$ dan2 orang pasien yang positif terhadap Salmonella typhii, Salmonella paratyphii A, Salmonella paratyphii B dan Salmonella paratyphii C. Dalam penelitian ini, sebagian besar pasien positif terhadap lebih dari 1 antigen Salmonella, hal ini dapat terjadi karena adanya reaksi silang sebelumnya dengan antigen antara spesies Salmonella yang sama yang memiliki antigen $O$ faktor 12 atau pernah terinfeksi dahulu dengan salah satu spesies Salmonella.
\end{abstract}

Kata kunci :Salmonella, Demam Tifoid, Uji Widal 


\section{PENDAHULUAN}

Penyakit infeksi dan menular masih memerlukan perhatian besar, disamping itu terjadi peningkatan kejadian pada penyakit menular salah satunya adalah demam tifoid.Terjadinya kejadian penyakit infeksi di negara berkembang khususnya demam tifoid sangat erat hubungannya dengan kebersihan perorangan yang kurang baik, sanitasi lingkungan yang jelek (seperti penyediaan air bersih yang kurang memadai, pembuangan sampah dan kotoran manusia yang kurang memenuhi syarat kesehatan, pengawasan makanan dan minuman yang tidak sempurna) serta fasilitas kesehatan yang tidak terjangkau oleh sebagian besar masyarakat dan masih rendahnya status sosial ekonomi dan rendahnya tingkat pengetahuan yang dimiliki kebanyakan masyarakat sehingga keadaan kesehatan lingkungan buruk dan status kesehatan menjadi semakin buruk (Widoyono, 2011). Adanya pertumbuhan bakteri pada makanan diduga berasal dari bahan baku yang kurang bersih dicuci atau wadah yang digunakan untuk mencuci peralatan padasaat proses pembuatan makanan tersebut tidak hygiene (Rizqoh \& Adiansyah 2019).

Penyakit demam tifoid merupakan suatu penyakit sistemik akut yang disebabkan oleh infeksi kuman Salmonella $s p$. Hingga saat ini penyakit demam tifoid masih merupakan masalah kesehatan di negara-negara tropis termasuk Indonesia. Kejadian demam tifoid di dunia sekitar 16 juta kasus setiap tahunnya, 7 juta kasus di Asia terjadi di Asia Tenggara, dengan angka kematian 600.000. Kejadian demam tifoid di Indonesia sekitar 760-810 kasus per 100.000 penduduk per tahun, dengan angka kematian 3,1-10,4\% (Nasronudin, 2011).

Prevalensi demamtifoid di Indonesia mencapai 1,7\%. Distribusi prevalensi tertinggi adalah pada usia 5-14 tahun(1,9\%), usia $1-4$ tahun $(1,6 \%)$, usia 15-24 tahun(1,5\%) dan usia $<1$ tahun $(0,8 \%)$.Prevalensi tertinggi demam tifoid di Indonesia terjadi pada kelompok usia 514 tahun (Purba I.E et al, 2016).

Berdasarkan Profil Kesehatan Provinsi Sumatera Utara tahun 2008, demam tifoid yang rawat jalan di Rumah Sakit menempati urutan ke-5 dari 10 penyakit terbesar yaitu 661 penderita dari 12.876 pasien rawat jalan (5.1\%), sedangkan rawat inap di Rumah Sakit menempati urutan ke-2 dari 10 penyakit

terbesaryaitu sebanyak 1.276 penderita dari 11.182 pasien rawat inap $(11.4 \%)$. Di kota Medan angka penderita demam tifoid oleh Dinas Kesehatan Provinsi Sumatera Utara tahun 2009 melaporkan bahwa proporsi demam tifoid dari 10 penyakit terbanyak pasien rawat inap di rumah sakit yaitu 8,5\% (1.681 kasus) dari 19.870 kasus. (Sari R.A,2013).

Dari data Rumah Sakit Advent Medan menunjukkan jumlah pasien rawat inap dengan diagnosa demam tifoid pada bulan Juli-Desember tahun 2017 berjumlah 853 orang dan prevalensi anak usia 5-14 tahun mencapai 93 kasus demam tifoid dengan pemeriksaan serum dengan metode Widal dan Tubex® TF.

Prevalensi tertinggi demam tifoid di Indonesia terjadi pada kelompok usia 514 tahun. Pada usia 5-14 tahun merupakan usiaanak yang kurang memperhatikan kebersihan diridan kebiasaan jajan yang sembarangan sehingga dapat menyebabkan tertular penyakit demam tifoid. pada anak usia 0-1 tahun prevalensinya lebih rendah dibandingkan dengan kelompok usialainnya dikarenakan kelompok usia ini cenderung mengkonsumsi makanan yang berasal dari rumahyang memiliki tingkat kebersihannya yang cukup baik dibandingkan dengan yang dijual di warung pinggir jalan yang memiliki kualitas yang kurang baik (Nuruzzaman $\mathrm{H}$ dan Syahrul F, 2016).

Pada umumnya diagnosis laboratorium penderita demam tifoid di Rumah Sakit dilakukan dengan pemeriksaan klinis dan penunjang diagnosis laboratorium dengan pemeriksaan secara serologis dengan Uji 
Widal (deteksi Ab Salmonella sp) dan Uji Tubex ${ }^{\circledR}$ TF yang dapat mendeteksi adanya antibodi IgM Salmonella typhii. Hal ini dilakukan karena pemeriksaan secara serologis dapat diperoleh dengan cepat untuk mendiagnosa pasien.

Salah satu dari uji serologis diatas yaitu Uji Widal.Uji Widal merupakan suatu metode serologi baku dan rutin digunakan sejak tahun 1896 yang dapat mengidentifikasi spesies Salmonella (Salmonella typhii, Salmonella paratyphii A, Salmonella paratyphii B, dan Salmonella paratyphii $C$ ) yang terdapat dalam tubuh penderita melalui reaksi antigen somatik $(\mathrm{O})$ dan antigen flagela $(\mathrm{H})$ dengan antibodi aglutinin dalam serum penderita sehingga terjadi aglutinasi. Pengenceran tertinggi yang masih menimbulkan aglutinasi menunjukkan titer antibodi dalam serum (Sari R.A, 2013).

Berdasarkan latar belakang pemikiran diatas, peneliti ingin mengetahui spesies apa sajakah yang dapat dilihat dari darah anak usia 5-14 tahun yang didiagnosa demam tifoid melalui Uji Widal di Rumah Sakit Advent Medan.

\section{METODE}

\section{Desain Penelitian}

Jenis penelitian yang digunakan adalah jenis penelitian deskriptif.Penelitian dilakukan di Rumah Sakit Advent Medan.Penelitian dilakukan pada Bulan Februari - Juli 2018.Populasi dalam penelitian ini adalah anak usia 5-14 tahun yang didiagnosa demam tifoid di Rumah Sakit Advent Medan.

Kriteria sampel pada penelitian ini adalah seluruh pasien yang memenuhi kriteria inklusi sebagai berikut : pasien dengan diagnosa positif demam tifoid ketika peneliti melakukan penelitian yang diketahui dari pemeriksaan serum dengan metode Widal dan Tubex ${ }^{\circledR}$ TF, usia 5-14 tahun, pasien rawat jalan yang ada di RS Advent Medan. Jumlah sampel yang diteliti adalah 10 orang.

\section{Pengambilan Darah}

Cuci tangan sesuai SPO cuci tangan, gunakan APD. Persiapkan alat plebotomi yang diperlukan. Terangkan kepada pasien bahwa akan dilakukan pengambilan darah pasien tersebut untuk bahan pemeriksaan laboratorium dengan tenang dan ramah; usahakan pasien senyaman mungkin.Minta persetujuan pasien, setelah di setujui maka persilahkan pasien untuk duduk di kursi tempat pengambilan darah bagi pasien yang bisa duduk, dan jika ternyata tidak bisa maka persilahkan pasien berbaring di atas tempat tidur yang sudah di sediakan.Sarankan pasien untuk merentangkan salah satu tangannya dan kemudian memasang tourniqiuet $\pm 10 \mathrm{~cm}$ (3 jari) diatas lipat siku, kemudian minta pasien mengepal tangannya. Pilihlah vena yang akan di ambil yaitu vena mediana cubiti atau vena cephalic. Lakukan perabaan untuk memastikan posisi vena. Kemudian bersihkan kulit pada daerah yang akan diambil darahnya dengan alkohol 70\% dan biarkan kering.Kemudian tusuk bagian vena yang telah di pilih (jika jarum telah masuk ke dalam vena, akan terlihat darah masuk kedalam semprit), minta pasien membuka kepalan tangannya dan lepaskan tourniquet. Ketika volume darah $3-5 \mathrm{cc}$, letakkan kapas kering ditempat suntikan lalu segera tarik jarum, tekan kapas. Lalu masukkan darah kedalam tabung tanpa antikoagulan. Beri Label yang lengkap pada tabung. Kemudian lihat apakah pada bekas tusukan darah masih terlihat keluar atau tidak, jika tidak, pasang plester. Ucapkan terimakasih kepada pasien, lalu bawa sampel ke laboratorium untuk dilanjutkan pada tahap pemeriksaan.

\section{Pembuatan Serum}

Ambil tabung berisi darah pasien (darah harus beku, sehingga mudah di centrifuge). Kemudian masukkan tabung kedalam centrifuge, atur keseimbangan (masukkan tabung lain di sisi arah berlawanan). Lalu putar selama 10-15 menit pada kecepatan $3000 \mathrm{rpm}$. Setelah di 
centrifuge, serum siap di gunakan untuk pemeriksaan.

\section{Pemeriksaan Serum dengan Uji Widal Metode Slide Test}

Pipet $20 \mu \mathrm{l}$ bahan pemeriksaan, letakkan pada masing-masing lingkaran diatas slide test. Kemudian teteskan 1 tetes, satu persatu suspensi antigen Salmonella dan masing-masing sub-tipe (O, $\mathrm{AO}, \mathrm{BO}, \mathrm{CO}, \mathrm{H}, \mathrm{AH}, \mathrm{BH}$ dan $\mathrm{CH})$ disamping bahan pemeriksaan tadi.Lalu homogenkan dengan menggunakan batang pengaduk. Lalu putar diatas rotator dengan kecepatan 100 rpm selama 1 menit. Baca hasil. Hasil dikatakan positif bila pada lingkaran slide test terdapat aglutinasi. Hasil dikatakan negatif bila pada lingkaran slide test tidak terdapat aglutinasi. Jika positif salah satu maka lakukan pengenceran.

\section{Pengenceran titer antigen $O$ dan antigen $\mathrm{H}$}

Pada slide tes Uji Widal yang positif dilakukan pengenceran untuk menentukan nilai titer. Pipet serum yang sudah diperiksa dan ada aglutinasinya sebanyak : Serum $10 \mu \mathrm{l}$ di tambah 1 tetes reagen $1 / 80$, Serum $5 \mu$ di tambah 1 tetes reagen 1/160. Lalu letakkan diatas slide tes yang bersih dan kering, homogenkan. Putar dirotator selama 1 menit dengan kecepatan $100 \mathrm{rpm}$. Baca hasil. Sebaiknya pembacaan pemeriksaan Uji Widal ini harus tepat 1 menit. Karena jika $<1$ menit akan didapatkan hasil negatif palsu. Sedangkan jika >1 menit maka akan mendapatkan hasil positif palsu.Nilai titer ditentukan berdasarkan pengenceran terakhir yang masih menunjukkan reaksi aglutinasi. Interpretasi Hasil dapat dilihat pada Tabel
1. Identifikasi bakteri Salmonella melalui antigen $\mathrm{O}$ dan antigen $\mathrm{H}$ Uji Widal dilakukan berdasarkan nilai titer $\geq 1 / 80$ pada setiap titer antigen $\mathrm{O}$ dan antigen $\mathrm{H}$ berdasarkan Sub tipenya tipe $(\mathrm{O}, \mathrm{AO}, \mathrm{BO}$, $\mathrm{CO}, \mathrm{H}, \mathrm{AH}, \mathrm{BH}$ dan $\mathrm{CH}$ ).

\section{HASIL DAN PEMBAHASAN}

Pemeriksaan Widal telah dilakukan terhadap 15 pasien suspek demam tifoid anak usia 5-14 tahun. Dari 15 pasien, ditemukan 10 sampel yang positif terdeteksi antibodi Salmonella sp. Pemeriksaan dilakukan di Laboratorium Rumah Sakit Advent Medan. Tabel 2 menjelaskan tentang hasil dari 10 sampel positif tersebut.

Hasil pemeriksaan Widal pada pasien yang positif memiliki antibodi terhadap antigen Salmonellaadalah sebagai berikut : 1 orang pasien positif terhadap Salmonella typhii (DT 01); 1 orang pasien positif terhadap Salmonella typhii dan Salmonella paratyphii B (DT 02); 3 orang pasien positif terhadap Salmonella typhii, Salmonella paratyphii $B$ dan Salmonella paratyphii $C$ (DT 03, DT 04 dan DT 05); 2 orang pasien positif terhadap Salmonella typhii, Salmonella paratyphii $A$ dan Salmonella paratyphii $C$ (DT 06, dan DT 07); 1 orang pasien positif terhadap Salmonella paratyphii A, Salmonella paratyphii B dan Salmonella paratyphii $C$ (DT 08) dan2 orang pasien yang positif terhadap Salmonella typhii, Salmonella paratyphii A, Salmonella paratyphii $B$ dan Salmonella paratyphii $C$ (DT 09 dan DT 10).

Tabel 1. Nilai Normal Titer Uji Widal

\begin{tabular}{lclc}
\hline \multicolumn{1}{c}{ Antigen Somatik $(\mathbf{O})$} & $\begin{array}{c}\text { Nilai } \\
\text { Normal }\end{array}$ & \multicolumn{1}{c}{ Antigen flagela $(\mathbf{H})$} & $\begin{array}{c}\text { Nilai } \\
\text { Normal }\end{array}$ \\
\hline Salmonella typhii $(\mathrm{O})$ & $1 / 40$ & Salmonella typhii $(\mathrm{H})$ & $1 / 40$ \\
Salmonella paratyphii A $(\mathrm{AO})$ & $1 / 40$ & Salmonella paratyphii $A(\mathrm{AH})$ & $1 / 40$ \\
Salmonella paratyphii $B(\mathrm{BO})$ & $1 / 40$ & Salmonella paratyphii $B(\mathrm{BH})$ & $1 / 40$ \\
Salmonella paratyphii $C(\mathrm{CO})$ & $1 / 40$ & Salmonella paratyphii $C(\mathrm{CH})$ & $1 / 40$ \\
\hline
\end{tabular}

Sumber : Standar Prosedur Operasional RS Advent Medan, 2018

Universitas Sari Mutiara Indonesia 
Tabel 2 .Hasil Identifikasi bakteri Salmonella pada penderita demam tifoid anak usia 5-14 tahun di RS Advent Medan

\begin{tabular}{|c|c|c|c|c|c|c|c|c|c|c|c|}
\hline \multirow{3}{*}{ No } & \multirow{3}{*}{ Kode } & \multirow{3}{*}{ Usia } & \multicolumn{8}{|c|}{ Hasil Pemeriksaan Bakteri Salmonella dengan Uji Widal } & \multirow{3}{*}{$\begin{array}{c}\text { Hasil Identifikasi Antigen O dan } \\
\text { Antigen H } \\
\text { Bakteri Salmonella dengan } \\
\text { Antibodi } \\
\text { Penderita demam tifoid }\end{array}$} \\
\hline & & & \multicolumn{4}{|c|}{ Antigen O } & \multicolumn{4}{|c|}{ Antigen $\mathrm{H}$} & \\
\hline & & & $\mathbf{O}$ & AO & BO & $\mathbf{C O}$ & $\mathbf{H}$ & $\mathbf{A H}$ & BH & $\mathbf{C H}$ & \\
\hline 1 & $\begin{array}{c}\text { DT } \\
01\end{array}$ & 11 & $1 / 80$ & $1 / 40$ & $1 / 40$ & $1 / 40$ & $1 / 40$ & $1 / 40$ & $1 / 40$ & $1 / 40$ & Salmonella typhii \\
\hline 2 & $\begin{array}{l}\text { DT } \\
02\end{array}$ & 14 & $1 / 80$ & $1 / 40$ & $1 / 80$ & $1 / 40$ & $1 / 160$ & $1 / 40$ & $1 / 40$ & $1 / 40$ & $\begin{array}{l}\text { Salmonella typhii dan Salmonella } \\
\text { paratyhpii } B\end{array}$ \\
\hline 3 & $\begin{array}{l}\text { DT } \\
03\end{array}$ & 11 & $1 / 40$ & $1 / 40$ & $1 / 80$ & $1 / 80$ & $1 / 80$ & $1 / 40$ & $1 / 80$ & $1 / 80$ & $\begin{array}{l}\text { Salmonella typhii, Salmonella } \\
\text { paratyhpii B dan Salmonella } \\
\text { paratyphii } C\end{array}$ \\
\hline 4 & $\begin{array}{l}\text { DT } \\
04\end{array}$ & 8 & $1 / 40$ & $1 / 40$ & $1 / 80$ & $1 / 80$ & $1 / 80$ & $1 / 40$ & $1 / 80$ & $1 / 80$ & $\begin{array}{l}\text { Salmonella typhii, Salmonella } \\
\text { paratyhpii B dan Salmonella } \\
\text { paratyphii } C\end{array}$ \\
\hline 5 & $\begin{array}{l}\text { DT } \\
05\end{array}$ & 5 & $1 / 160$ & $1 / 40$ & $1 / 40$ & $1 / 80$ & $1 / 160$ & $1 / 40$ & $1 / 80$ & $1 / 40$ & $\begin{array}{l}\text { Salmonella typhii, Salmonella } \\
\text { paratyhpii B dan Salmonella } \\
\text { paratyphii } C\end{array}$ \\
\hline 6 & $\begin{array}{l}\text { DT } \\
06\end{array}$ & 12 & $1 / 80$ & $1 / 80$ & $1 / 40$ & $1 / 80$ & $1 / 40$ & $1 / 40$ & $1 / 40$ & $1 / 40$ & $\begin{array}{l}\text { Salmonella typhii, Salmonella } \\
\text { paratyhpii A dan Salmonella } \\
\text { paratyphii C }\end{array}$ \\
\hline 7 & $\begin{array}{l}\text { DT } \\
07\end{array}$ & 8 & $1 / 160$ & $1 / 40$ & $1 / 40$ & $1 / 40$ & $1 / 160$ & $1 / 80$ & $1 / 40$ & $1 / 80$ & $\begin{array}{l}\text { Salmonella typhii, Salmonella } \\
\text { paratyhpii A dan Salmonella } \\
\text { paratyphii C }\end{array}$ \\
\hline 8 & $\begin{array}{l}\text { DT } \\
08\end{array}$ & 6 & $1 / 40$ & $1 / 40$ & $1 / 80$ & $1 / 160$ & $1 / 40$ & $1 / 80$ & $1 / 80$ & $1 / 320$ & $\begin{array}{l}\text { Salmonella paratyhpii } A \text {, } \\
\text { Salmonella paratyhpii } B \text { dan } \\
\text { Salmonella paratyphii } C\end{array}$ \\
\hline 9 & $\begin{array}{l}\text { DT } \\
09\end{array}$ & 14 & $1 / 80$ & $1 / 80$ & $1 / 40$ & $1 / 160$ & $1 / 160$ & $1 / 160$ & $1 / 80$ & $1 / 40$ & $\begin{array}{l}\text { Salmonella typhii, Salmonella } \\
\text { paratyhpii A, Salmonella } \\
\text { paratyhpii B dan Salmonella } \\
\text { paratyphii } C\end{array}$ \\
\hline 10 & $\begin{array}{l}\text { DT } \\
10\end{array}$ & 7 & $1 / 320$ & $1 / 80$ & $1 / 80$ & $1 / 80$ & $1 / 320$ & $1 / 80$ & $1 / 80$ & $1 / 160$ & $\begin{array}{l}\text { Salmonella typhii, Salmonella } \\
\text { paratyhpii A, Salmonella } \\
\text { paratyhpii B dan Salmonella } \\
\text { paratyphii } C\end{array}$ \\
\hline
\end{tabular}

Hasil identifikasi bakteri Salmonella pada penderita yang didiagnosa demam tifoid yang tertera di tabel 1.diperoleh hasil 1 orang penderita yang memiliki antibodi terhadap bakteri Salmonella typhii. Maka persentase hasil identifikasi Salmonella typhii pada anak usia 5-14 tahun yang didiagnosa demam tifoid adalah $10 \%$.

$$
\text { Hasil identifikasi bakteri }
$$

Salmonella pada anak usia 5-14 tahun yang didiagnosa demam tifoid yang tertera di tabel diatas diperoleh hasil 1 orang penderita yang memiliki antibodi terhadap dua antigen Salmonella yaitu Salmonella typhii dan Salmonella paratyphii $B$. Persentase hasil identifikasi anak usia 5-14 tahun yang didiagnosa demam tifoid yang

Universitas Sari Mutiara Indonesia

DOI positif terhadap dua jenis antigen Salmonella adalah $10 \%$.

Dalam penelitian ini, ada 6 orang yang positif terhadap tiga jenis antigen Salmonella yaitu 3 orang terhadap Salmonella typhii, Salmonella paratyphii B dan Salmonella paratyphii $C, 2$ orang terhadap Salmonella typhii, Salmonella paratyphii A dan Salmonella paratyphii $C$ dan 1 orang terhadap Salmonella paratyphii A, Salmonella paratyphii $B$ dan Salmonella paratyphii $C$. Maka persentase hasil identifikasi anak usia 5-14 tahun yang didiagnosa demam tifoid yang positif terhadap tiga jenis antigen Salmonella adalah $60 \%$.

Dalam penelitian ini juga terdapat 2 orang yang positif terhadap empat jenis antigen Salmonella yaitu terhadap 
Salmonella typhii, Salmonella paratyphii $A$, Salmonella paratyphii $B$ dan Salmonella paratyphii $C$. Maka persentase hasil identifikasi anak usia 5-14 tahun yang didiagnosa demam tifoid yang positif terhadap empat jenis antigen Salmonella adalah $20 \%$.

\section{PEMBAHASAN}

Demam tifoid adalah infeksi akut pada saluran pencernaan yang disebabkan oleh bakteri Salmonella typhi dan Salmonella paratyphi A, B, dan C. Gejala dan tanda kedua penyakit tersebut hampir sama,tetapi manifestasi klinis paratifoid lebih ringan. Kedua penyakit diatas disebut tifoid. Demam tifoid dikenal juga dengan sebutan Typhus abdominalis, Typhoid fever, atau enteric fever. Istilah tifoid ini berasal dari bahasa Yunani yaitu typhos yang berarti penderita demam dengan gangguan kesadaran (Widoyono, 2011).

Pada anak-anak demam tifoid dapat terjadi akibat kurang memperhatikan kebersihan diridan kebiasaan jajan yang sembarangan sehinggadapat menyebabkan tertular penyakit demam tifoid (Nuruzzaman H dan Syahrul F, 2016).

Diagnosa laboratorium dengan tes serologi dapat dilakukan untuk identifikasi bakteri Salmonella yaitu dengan Uji Widal. Uji Widal merupakan suatu metode serologi baku dan rutin digunakan sejak tahun 1896. Prinsip uji Widal adalah memeriksa reaksi antara antibodi aglutinin dalam serum penderita yang telah mengalami pengenceran berbeda-beda terhadap antigen somatik (O) dan flagela (H) yang ditambahkan dalam jumlah yang sama sehingga terjadi aglutinasi. Pengenceran tertinggi yang masih menimbulkan aglutinasi menunjukkan titer antibodi dalam serum. Semakin tinggi titernya, semakin besar kemungkinan infeksi ini (Sari R.A, 2013).

Dalam pemeriksaan uji Widal, hasil positif tinggi atau meningkat titer $\mathrm{O}$ menyatakan bahwa telah terjadi infeksi aktif (Ig M).Titer $\mathrm{H}$ tinggi akan adanya imunisasi atau sudah pernah terinfeksi (Ig G).Uji Widal juga menjadi gambaran identifikasi jenis Salmonella apa yang menginfeksi pasien melalui reaksi antara antigen $\mathrm{O}$ dan $\mathrm{H}$ Salmonella typhii, Salmonella paratyphii A, Salmonella paratyphii B dan Salmonella paratyphii $C$ dengan serum penderita. Tes aglutinasi dengan anti serum serapan untuk antigen $\mathrm{O}$ dan $\mathrm{H}$ yang berbeda merupakan dasar untuk klasifikasi Salmonella secara serologi (Kuswiyanto, 2016).

Namun banyak hal yang harus diperhatikan dalam pemeriksaan uji Widal, beberapa faktor yang bisa menyebabkan negatif dan positif palsu. Pada pemeriksaan uji Widal Hasil negatif palsu dapat terjadi jika darah diambil terlalu dini dari fase tifoid, pembacaan hasil dibawah 1 menitdan pemberian antibiotik. Hasil positif palsu uji Widal dapat terjadi akibat vaksin tifoid, pembacaan hasil diatas 1 menit dan cross reacting antibodies yaitu reaksi silang dengan jenis enterobactericeae lainnya(Wardhani, 2011).

Dalam penelitian ini, terdapat pasien yang positif terhadap lebih dari 1 antigen Salmonella, hal ini dapat terjadi karena adanya reaksi silang sebelumnya dengan antigen antara spesies Salmonella yang sama yang memiliki antigen $\mathrm{O}$ faktor 12 atau pernah terinfeksi dahulu dengan salah satuspesies Salmonella (Kuswiyanto, 2014).

\section{SIMPULAN}

Berdasarkan hasil penelitian yang dilakukan di Rumah Sakit Advent Medan terhadap 10 sampel yang positif terdeteksi antibodi Salmonella sp dengan metode Widal, terdapat 9 pasien yang positif terhadap lebih dari 1 antigen Salmonella, hal ini dapat terjadi karena adanya reaksi silang sebelumnya dengan antigen antara spesies Salmonella yang sama yang memiliki antigen $\mathrm{O}$ faktor 12 atau pernah terinfeksi dahulu dengan salah satu spesies Salmonella. 


\section{DAFTAR PUSTAKA}

Jawetz, dkk.2010, Mikrobiologi Kedokteran. Jakarta: Penerbit Buku Kedokteran EGC.

Kuswiyanto. 2015, Bakteriologi 1: Buku Ajar Analis Kesehatan. Jakarta: Penerbit EGC.

Kuswiyanto.2016,Bakteriologi 2: Buku Ajar Analis Kesehatan. Jakarta: Penerbit EGC.

Maryunani A. 2010, Ilmu Kesehatan Anak Dalam Kebidanan. Jakarta: TIM.

Nasronudin.2011, Penyakit Infeksi di Indonesia Solusi Kini \& Mendatang.Edisi Kedua. Surabaya: Pusat Penerbitan dan Percetakan Unair.

Nuruzzaman H, Syahrul F.2016,Analisis Risiko Kejadian Demam Tifoid Berdasarkan Kebersihan Diri dan Kebiasaan Jajan di Rumah. Jurnal Berkala Epidemiologi; 4: 74-86.

Poeloengan M, Komala I, Noor SM. 2014, Bahaya Salmonella Terhadap Kesehatan. Lokakarya Nasional Penyakit Zoonosis.

Purba IE, Wandra T, Nugrahini N, Nawawi S, Kandun N. 2016, Program Pengendalian Demam Tifoid di Indonesia: tantangan dan peluang. Media Litbangkes.

Radji M. 2010, Buku Ajar Mikrobiologi: Panduan Mahasiswa Farmasi \& Kedokteran. Jakarta: Penerbit Buku Kedokteran EGC.

Rizqoh D, Adyansyah. 2019. Identifikasi Salmonella sp. pada jus wortel yang diperjualbelikan di sekitar Jalan Irian Tanjung Morawa Kabupaten Deli Serdang Sumatera Utara. Jurnal
Analis Laboratorium Medik, 4(1): 20-23.

RS Advent. 2018, Standart Prosedur Operasional. Medan

Sari RA. 2013, Profil Penderita Demam Tifoid pada Orang Dewasa di RSUD DR.PRINGADI Medan pada April 2012 - April 2013. [Skripsi]. Medan: Fakultas Kedokteran Universitas Sumatera Utara.

Sucipta MA. 2015, Baku Emas Pemeriksaan Laboratorium Demam Tifoid Pada Anak. Jurnal Skala Husada; 12: 22-26.

Syahrurahcman A, Chatim A, Amin KWS, Anis K, Santoso SUA, Harun BMS, et al. 2010, Buku Ajar Mikrobiologi Kedokteran. Jakarta: Penerbit Binapura Aksara Publisher.

Wardhani EK. 2011, Pemeriksaan Laboratorium dalam Menegakkan Diagnosis Demam Tifoid. [Karya Tulis Ilmiah]. Malang: Universitas Muhammadiyah Malang.

Widoyono.2011, Penyakit Tropis Epidemiologi, Penularan, Pencegahan \&Pemberantasannya. Edisi Kedua. Jakarta: Penerbit Erlangga 